This item was submitted to Loughborough's Research Repository by the author.

Items in Figshare are protected by copyright, with all rights reserved, unless otherwise indicated.

\title{
Space, use and university libraries - the future?
}

PLEASE CITE THE PUBLISHED VERSION

http://www.ashgate.com/isbn/9781409423829

\section{PUBLISHER}

() Ashgate Publishing

VERSION

VoR (Version of Record)

LICENCE

CC BY-NC-ND 4.0

REPOSITORY RECORD

Childs, Sarah, Graham Matthews, and Graham Walton. 2019. "Space, Use and University Libraries - the Future?". figshare. https://hdl.handle.net/2134/11496. 
This item was submitted to Loughborough's Institutional Repository (https://dspace.lboro.ac.uk/) by the author and is made available under the following Creative Commons Licence conditions.

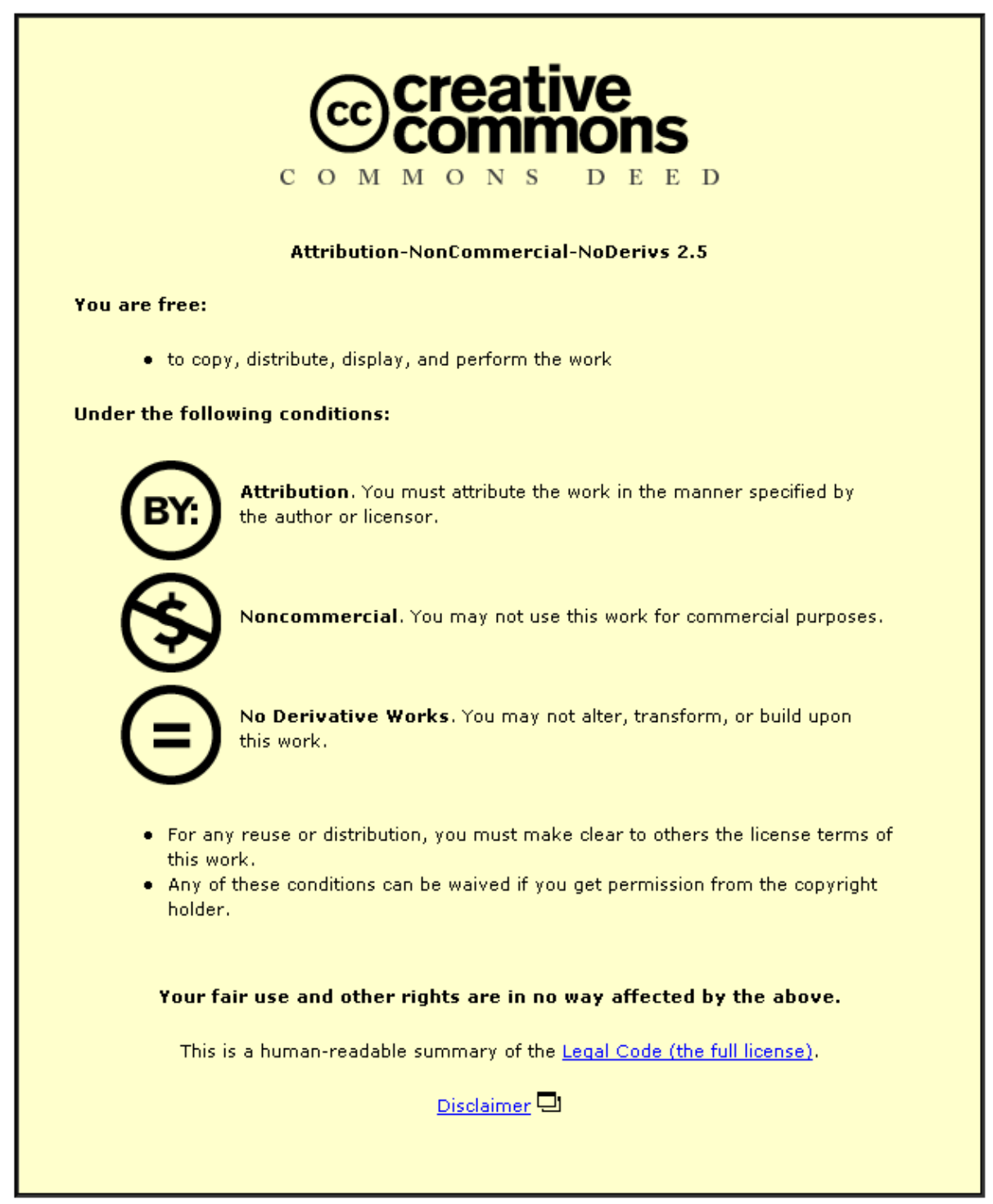

For the full text of this licence, please go to: http://creativecommons.org/licenses/by-nc-nd/2.5/ 


\title{
(C) Copyrighted Material \\ Chapter 14 \\ Space, Use and University Libraries - \\ The Future?
}

\author{
Sarah Childs, Graham Matthews and Graham Walton
}

The chapters in this book have reflected various developments, trends, issues, and opportunities relating to university academic libraries' physical space up until 2012. This chapter will attempt to give an insight into what will shape university libraries and their physical space in the future. Whilst predicting the future is difficult, the importance of having at least some idea of future trends has been pointed out by several authors (Stahl 1987, Caldwell 2006): it allows head librarians and managers to plan their buildings accordingly. There is also a somewhat woolly idea of what 'the future' means in many predictions. Whilst some of the literature predicting the future suggests a specific date or period of time by which their suggestions could become reality (Line 1993, Raitt 1993), many are unclear whether 'the future' means five years, 15 years, or 50 years (Orne 1977, Kapp 1987). This has begun to change with projects such as the recent JISC Libraries of the Future Project (JISC 2009), which looks at trends over the next ten years, and the 2010 report from the Association of College and Research Libraries (ACRL) which is interested in developments over the next fifteen years (Staley and Malenfant 2010). Nevertheless, what is missing from the literature is an in-depth look at how physical space may be used in the future.

A glimpse of this is provided through the findings of a small-scale project undertaken in 2011 as part of an MA dissertation by Sarah Childs (2011) supervised by the editors. The insight and predictions proposed in this chapter are based upon views gathered from a range of individuals through using an adaptation of the Delphi technique which is recognized as a good method for forecasting the future (Linstone and Turoff 1975: 4), due to its use of numerous experts. Ultimately, the trends identified tend to be the result of a consensual opinion amongst more than one participant - however, if not all of the participants agreed then this is noted. The stages of the research were:

- Round $1-$ a review of the literature;

- Round 2 - scoping interviews were carried out with a small number of interested parties;

- Round 3 - a questionnaire survey (see Appendix 14A) was distributed to a different, larger group of experts. The questionnaire was sent to 35 people, with 22 respondents, a 63 per cent response rate. The sample was intended to 
be purposive - senior librarians and academics with interest and experience in managing space were identified. The questionnaire required respondents simply to (strongly) agree or (strongly) disagree in their answers to a series of statements;

- Round 4 - a set of interviews was carried out with a small number of participants selected from the questionnaire respondents.

There were responses to the survey from Australia, Canada, and the USA, and one of those interviewed was from Canada. However, it is true to say that the respondents and interviewees have a UK bias. Nevertheless, it would have been difficult to have had participants from a large number of different nations, so this was at least explored to some degree. Those who participated did come from a wide range of institutions, from a professor at a research university to a deputy librarian at a distance learning institution. Therefore, differences and similarities between different kinds of universities were explored and explicitly discussed with the participants. The discussion resulting from this Delphi study revolves around some key familiar themes: technology, shared services, campus library space.

\section{Technology}

Technological change was generally seen as an important feature of space use in university libraries, both past and present. There was a general feeling that it had and would continue to change library space rather than eliminate it. For example, in the questionnaire, over 90 per cent of respondents disagreed with the idea that increasing digital information use would make physical libraries redundant. Two of the remarks in response to the idea that technology would destroy library space were markedly terse and sceptical: 'previous predictions of this type have not proved correct' (Respondent 5) and 'not for the next 30-50 years' (Respondent 12). Technology actually featured as one of the reasons for justifying library space to a university vice chancellor (three respondents).

Three broad topics were discussed in both the survey and the interviews in relation to technology: the effect of technological development (e.g. mobile devices), the digital divide, and digitization of resources. Respondent 5 discussed how the development of shared computing services had been associated with end-user access to electronic information. Technology would have an impact on physical space, according to Respondent 5 , as it would mean the ongoing need for helpdesks to assist people with using technology. All interviewees either felt there would not be a digital divide, that it would be much smaller in the future, or that it would not necessarily be a 'divide' between younger tech-savvy students and older technophobes, with two respondents citing the 'Google Generation' report (JISC 2007) as evidence of this.

Both Respondent 5 and Respondent 3 felt that students would continue to use technology in order to access information, but alongside physical resources 
such as archives and special collections. Therefore, it was perceived that space in the future would have to be set aside for both these purposes. Respondent 5 did, however, also discuss how in the United States there was a different model for Learning Commons which involved a total separation between the technological and more 'traditional' library spaces, perhaps indicating a continued difference between the United Kingdom and the United States in the future.

Digitization was perceived by Respondent 3, Respondent 8 and Respondent 16 as being a major part of the trend. However, there was a perception that this route may present difficulties. Respondent 3 perceived a difficulty in faculty wanting physical copies to be available whilst Respondent 16 believed that some difficult decisions would have to be made about what is digitized.

\section{Shared Services}

As over 80 per cent of respondents to the survey believed shared services would increasingly be a feature of library buildings in the future, the interviewees were all asked which kind of services they believed would share with university libraries. In the 'other comments' section on the original survey question about this topic, there were also some suggestions as to what these would be. Two survey respondents mentioned Learning Commons, which was also expanded on by the interview respondents. Respondent 16 mentioned that their experience was that academic support colleagues from other departments in the university would move into the building. The fact that the library building was open for longer hours than other services was seen as a major reason for moving these academic services to their building. One respondent (Respondent 5) believed that the type of services would depend on the type of university. A distinction was made by this respondent between 'new' universities (i.e. former polytechnics and colleges) and more established 'research' universities. Research universities were seen as possibly pairing up with 'study skills and learning services, but potentially also a service like the Careers Service'. These services would also be seen in new universities, although at these institutions 'things like counselling and financial assistance' would be a feature of shared buildings.

Initiatives related to teaching and learning were perceived by two of the interviewees as having an effect on shared space. One of the interviewees had an experimental PC Lab at her campus, which was seen as possibly being a feature of the future. Another predicted faculty using space in the library building - in her own campus this was seen as being in the form of space for faculty and students to collaborate in the library, but at other universities it was perceived that this shared space may be for the faculty themselves to teach in, particularly for joint honours programmes and other more generic courses.

The idea of commercial use of library buildings was also broached with the interviewees as there were two respondents to the survey who mentioned this idea. The further possibility of hiring out rooms was mentioned by three participants. 
This was not necessarily to be used by commercial organizations, as Respondent 3, for example, mentioned hiring out rooms to community groups. Respondent 5 differed in her views as she felt that it was unlikely that library space would be used in a commercial way at a research university. Of the other respondents, Respondent 16 and Respondent 3 both felt that commercial research partners may end up sharing library space. Respondent 3 stated:

... so it isn't a long stretch to see OK, well maybe if ... [a commercial research partner] says 'We don't have a library of our own, we want to use your services. We're willing to pay to renovate a room for our staff to work in.' You know, would we consider that? We'd have to think about it - I'm just opening up that that might be a possibility.

\section{Campus Library Space}

Nearly a third disagreed or strongly disagreed with the statement that there would be a physical library on every campus in 2021. Most only agreed rather than strongly agreed with the statement, suggesting reluctance to strongly commit to the idea of every campus having a physical library. Two respondents said there would be some movement away from this idea. There were three interesting responses to the statement:

- 'It may not be a library according to the current definition' (Respondent 17)

- 'Still ... [a] need for physical facilities ... but not necessarily at every campus' (Respondent 18)

- 'The library as a space still seems very important to staff and students alike' (Respondent 10).

Respondent 5 stated that:

[I]f the campuses are far apart and there are significant numbers of students on those campuses than I think that library spaces will continue to be required.

This statement perhaps confirms the wider feeling amongst survey respondents that campus library space will continue to be important, but that smaller library campus space may be threatened, and that these campus libraries will only survive under certain conditions.

\section{Student Population}

Nine out of 16 respondents who answered the question in the survey about other trends that they thought would be significant in the future believed that a changing 
student population would be a big factor. This was expected to have a range of implications, from '[increased] student employment means libraries need longer opening hours' (Respondent 5) to an Australian respondent who stated that, in their country, 'most universities are looking at new ways to engage with and attract new enrolments' (Respondent 18). This theme was also mentioned by the interviewees. In the UK, the rise in tuition fees, alongside other changes in higher education funding, has created some doubt as to the future composition of the student body. However, it was felt by Respondent 16 that the 'student population is likely to stay reasonably as it is now ... students seem to be ... inured to debt'. Nevertheless, she also asked the question 'Are we looking at a truly life-long learning society? So we would be expecting people to come back into higher education repeatedly during their careers.' She felt that this would help 'maintain' library space.

However, one of the survey respondents also mentioned a plan for their university to recruit more research students - hence the need to have space for researchers in the library. This was also one of the reasons behind the changes to library space at Respondent 3's university in favour of researchers:

We want to do that [support graduate research] ... our priority is the graduate students partly because the university's priority is improving the graduate student experience.

\section{Learning and Teaching Methods}

One of the survey questions asked how changes in teaching and learning would impact on library space in higher education. The most consistent theme mentioned was technology - mentioned by eight out of 22 respondents. E-resources and mobile devices were particularly emphasized. The answers specifically mentioning teaching and learning indicated changes such as more group work, problem-based learning, and independent learning; one (Respondent 8) mentioned the idea of students being more involved in research (student as producer).

One respondent made the following comment on the 'any further comments' question right at the end of the survey:

I feel we have let pedagogical changes drive our development of space rather than using our professional expertise to drive in our own direction.

This idea was put to the interviewees and all of them disagreed with the idea. Three of the interviewees made comments along these lines:

I think it's true that the pedagogical change has strongly influenced library space.

But my feeling is that that's not a bad thing. (Respondent 5) 
There was a feeling that this would continue in the future, and there would not be any significant changes in the future that would prioritize the values of professional librarians over pedagogical change. Respondent 16 had a slightly different approach as she felt that libraries were not supporting the pedagogy of the lecturers, but were actually, in many cases, leading the way in terms of changing teaching and learning methods:

I think pedagogy tends to drag, and that ... academics are very traditional beasts on the whole ... so I think particularly if you look at recent library developments people have tried to get ahead of the game a bit.

This was a notable viewpoint in that it runs contrary to the traditional view that libraries are there to support whatever the wider university is doing. Respondent 16 took the attitude that in terms of the library space and teaching and learning methods it was the role of the library to innovate and advocate for change:

I mean the best library planning, the best library design takes place in harmony with research and teaching and learning drivers ... But I think we need to be in there, and getting ahead, pushing. And presenting new ideas.

\section{Research Space}

The idea that the library is increasingly redundant for researchers and academics was agreed with by most respondents to the survey, though five comments were received that this was heavily dependent on the choice of subject, with the idea that arts, humanities, and social sciences used the library far more often. This was further confirmed by comments by three of the interviewees:

- 'It's certainly true that ... academic staff and the researchers make very little use of our library space. Well I would have to qualify that - there is a certain amount of usage, in the humanities areas.' (Respondent 5)

- 'Library space I think tends to be used when researchers don't have a home somewhere else. So we tend to see more arts-based researchers here. (Respondent 16)

- 'So we're trying to provide that kind of graduate student research space ... it's mostly for arts and humanities, social sciences. Because the engineers and scientists want their labs.' (Respondent 3)

This last comment also reflects a common idea mentioned several times in the survey responses of having a dedicated space for researchers. There was perhaps a perception amongst some respondents (although by no means all) that there had been a great deal of focus on improving libraries for undergraduates by responding 
to changes in teaching and learning, and over the next few years libraries would have to make sure that they served researchers and academics too.

One respondent to the survey spoke about the change in their institution to an idea deemed 'student as producer', whereby students would be far more involved with research. It was predicted that this could have an impact on space if adopted more widely. However, this was not seen as particularly innovative by Respondent 5, who stated that 'all our undergraduate students do research so I don't really see that as anything very new or novel'. For another of the interviewees, Respondent 3, this was an extremely important development that was also occurring under a different guise in her university, and in many others:

In terms of supporting undergraduate research one of the things we want to encourage them to think about is when they produce something - whether it's an essay or a fourth-year research paper, whatever. That is a valuable piece of knowledge that needs to be shared. It isn't something just to hand in for marking and then throw away. And so we have developed our institutional repository with the idea it will take not only theses, dissertations, and research articles but fourth-year undergraduate research papers and the data associated with those papers.

Providing space for researchers to do their work, and for faculty and students (and, indeed, students and students) to interact in the library was seen by Respondent 3 as an absolutely essential part of this.

\section{Alternative Learning Spaces}

This was mentioned in questionnaire responses; one person commented that 'library spaces will be challenged by the rise of discipline-based studios that will be able to be used by students outside of teaching times' (Respondent 20). This was also discussed by Respondent 16 in her interview, where she stated that the university had created these kinds of spaces on campus, but it was a very 'piecemeal' approach. Her belief was that these kinds of spaces would continue, but that it was very variable as to how prominent or coordinated they would be. Apart from the one questionnaire respondent, there does not seem to be a generalized belief that these kinds of spaces present a major threat to university library space in the future.

\section{Symbolic Value of the Library}

The way that people will view libraries in the future was seen as one of the most continuous and consistent trends, amongst all the change and evolution of other areas such as technology and print collections. A questionnaire respondent felt that 
students should already be viewing the library as more of a place of learning than a warehouse of books. In the question where respondents had to justify library space to their university vice-chancellor, it was very notable that half of the respondents to the survey also mentioned the symbolic value and perceptions of the library with comments such as 'students regard it as the central space for engagement with other students and with learning on the campus' (Respondent 11). Or, put more simply, 'the "library as place" remains important to students' (Respondent 22).

Three interviewees expanded on this theme very strongly. The exception was the interviewee working at a distance learning institution, as her library space did not have this kind of association. However, a selection of the comments from the other three gives an idea of the importance of the concept:

- 'The library is one of those places where ... it kind of has that gravitas, that identity. Usually it sends a message of somewhere secure to go and be ... to actually study.' (Respondent 16)

- 'I think library space has featured in education for a long time and I don't think it's going to disappear. We've been there since Alexandria ... you can't really get rid of us.' (Respondent 16)

- 'Students associate the library with academic activity.' (Respondent 5)

- 'They [students] come here because it's the heart of the university ... They still see it [the library] as the heart of their experience here, which is fantastic ... whatever changes we're going through, the students still see us as important.' (Respondent 3)

Additionally, it should be noted that these replies were not the result of a question on the interview schedule - they were arrived at independently.

\section{Collection Management and Preservation (Physical Resources)}

Despite all the discussion of library space being used for new technology and new research, teaching and learning initiatives, the need for continued careful management of physical collections was mentioned by several participants in both the interviews and questionnaires. The consensus from the questionnaire seemed to be that there would be a decrease in volume of printed collections in the future. One respondent to the survey even went as far as to predict the 'disappearance of printed collections for research' (Respondent 16). Several respondents discussed the death of the printed journal. In the interviews, Respondent 9 stated that at her library, a distance learning institution, they were 'getting rid' of print collections and that their numbers were 'reducing significantly'.

Respondent 3 felt that their archive was still important, and said that currently, although 'they [researchers] could do it digitally ... [they] generally like to look at the primary material'. Respondent 16 agreed that despite digitization initiatives, 'they don't seem to be slowing the growth of our physical collections at the 
moment'. She felt that libraries would increasingly work in partnership with one another in order to preserve collections at a regional or national level, as libraries would not be able to afford to keep such broad physical collections. Certain strategies would have to be formulated:

I think probably the sensible approach for libraries is to look at their physical resources and say: 'How much of that do we really need?' What are the unique selling points of a library attractive to a researcher in ... Icelandic - for instance? So you may find what universities will do is to concentrate their collections on what their really unique strengths are.

\section{Staff Space}

The idea of library staff and space was rarely mentioned in the literature on the subject and it was really only in the scoping interviews that it came up as a topic. However, it was felt to be an important avenue to explore, and in the survey there was some disagreement as to whether there will be less space for staff in the future. The comments in response to the question indicated a certain ambivalence, exemplified by one respondent who stated '[I'm] ... a bit neutral on this ...' (Respondent 18). A narrower question was included in the interviews, which was specifically to do with embedded librarians, but broader issues to do with space for staff were mentioned by two interviewees. Respondent 9 and Respondent 3 both discussed how they were downsizing staff space in their buildings. Respondent 3 said that in her library's rebuilding project, the focus was on students rather than staff:

So in some ways, staff space has reduced, and decreased in size. And you know the staff are not terribly happy about this. My own view is that ... you know we've got the money from the government to create student space, not staff space.

For this respondent, the library staff getting out of their office space and going into the library and into faculties was seen as a very important part of their role in the future. The use of embedded librarians was mentioned by survey respondents and was viewed as a potentially positive development by three of the interviewees. However, there were perceived difficulties with the idea:

- 'I think that libraries are unlikely to have enough staff to really implement that model to a significant degree.' (Respondent 5)

- 'It's more of a question of getting the librarians who are in those positions to want to do that ... some of the older librarians are perhaps not so wedded to the idea of going out.' (Respondent 3)

- 'The faculties say: "we've got no room to hold them".' (Respondent 3) 
One of the interviewees was sceptical about the idea as 'they [librarians] belong to the library, they don't belong to the faculty' (Respondent 9). Embedding librarians was seen to be risky by this respondent as it was felt that it would be difficult to manage and would create inconsistency.

\section{Conclusions}

The research has shown the growing importance of identifying trends and being 'future-ready', something many of the chapter authors have noted. The continued gloomy economic outlook in many parts of the world, and the reforms in higher education in England, mean that university libraries, including their space, are likely to be subject to financial cuts. The research demonstrated the continued importance of university library space, alongside the huge pace of change in library space in the past two decades discussed in the literature review. This has been fuelled largely by technological developments - but also the changes in teaching methods and other trends. The unpredictability of the modern world, including the world of libraries, is one of the reasons for the increased interest in identifying trends through methods such as scenario planning. This small project threw up for the 2010s and beyond:

- Technology - increased use of mobile and other technology; reduction in the digital divide, digitization of resources

- Student population - likely to be more demanding

- Learning and teaching - further adaptation of space for evolving teaching methods

- Increase in shared services - technology, faculty and hiring of rooms

- Continued symbolic importance of libraries

- Decline in physical resources

- Possible disappearance of campus library space

- Importance of physical appearance

- Changes to staff space - possible decline and embedding of librarians

- Variety of importance of alternative (non-library) space.

There was, though, some disagreement over these trends. For example, whilst one of those interviewed felt that the development of space for researchers was absolutely key to library space in the future, another felt that researchers were already well catered for with library space. This disagreement over some issues is partially a testament to the variety of people who took part and prioritized at their universities. For example, the interviewee who was based at a distance learning institution did not place a high value on the building, whilst for one of the survey respondents, the library building was so important that it would be used as a student recruitment tool. 
Nearly all of those participating felt that technology will have a big effect on library space, although there was a certain amount of uncertainty as to what the exact implications are. For example, the degree to which e-books take off was seen by some participants as having a strong influence on space, but they felt that it was unclear exactly how much this would happen. Student population was also seen as a key trend as students became more demanding of libraries generally, including space, because of increased university fees (for English students). The possibility of more adult learners came up in the survey, although the idea that they would necessarily use the physical collections and space more due to technological ineptitude was challenged by two interviewees.

Library buildings were seen as likely to diversify in terms of the services available in them - with academic services, faculty space, and exhibit space all being mentioned as possibilities. The physical appearance of libraries was perceived as becoming more important in order to keep them attractive for demanding paying students who had other learning space available to them. There was a lack of agreement about the trends in alternative learning spaces such as 'learning pods', with one interviewee believing their development would largely be based on local factors. Campus library space was usually perceived as surviving, though there were some reservations expressed about this.

Whilst pedagogy was still seen as an important influence on library space, the role of researchers and library space was perhaps perceived as gaining in importance, having previously been neglected at some institutions. At the lower end, this entailed having certain areas set aside for researchers in the future, but at its most ambitious, this was part of a whole new relationship between the library, faculty, and the university as a whole. For example, one interviewee was building a Discovery Centre at her library to enable faculty to interact with students in the library, at the same time as the university was encouraging students to see their work as valuable research contributing to a body of knowledge.

Just as researchers are being enticed into the library, library employees may be being sent out of the library. Some development in terms of roving or embedded librarians was seen as probable. However, this was likely to be limited by budgets and willingness of staff and faculty to participate in this. This trend could be seen as diminishing space, but in another way; if libraries are their staff, it could be perceived as an extension of space.

What was clear from the beginning of the research was the huge esteem in which the library building in its physical form is held. Despite the 'death of the printed journal' and the likely decline in physical collections, there was also a strong feeling that the way the library is perceived by students and faculty alike is largely positive. Although the reasons for people going to the library may be changing from going to pick up a book to going to engage with their classmates and professors in discussion, the view of the university library as a specific dedicated space for learning and education will remain. This is, above all else, how physical libraries will remain relevant in the digital age. 
Students are likely to be more demanding of space. Therefore, libraries need to seek and respond to student feedback in ever more intelligent and innovative ways, to keep ahead of the trends. This will involve, for example, consulting students before they even begin their courses, and getting feedback from library staff on the ground to keep ahead of the trends. The way that library staff use library space should be regularly reviewed. With mobile technology developments, taking some library staff out of the library and into departments for some or all of their working day should be investigated. The reduction of physical collections is a key trend that will affect all academic libraries in the coming years. This space should not be 'taken away' from the library; rather, it should be used for other important purposes, such as providing a space for postgraduate students and researchers. The development of shared services and shared space is another key trend. Libraries need to position themselves within their institutions as a vital service, to make sure that these shared services are implemented sensitively and appropriately, so that the library remains the most important part of these shared services.

\section{Endnote}

One of the editors has recently visited Aberdeen University. People doubtful about the future purpose, need, and rationale for university library space would have their uncertainties resolved by visiting Aberdeen University Library in Scotland (see Chapter 6). The building from the outside is unique and provides a landmark from the ground, sea, and sky. The walkway to the Library is spacious, well designed, and prepares the Library user before they enter the building. When in the Library, the views from the higher floors are inspirational, looking over Aberdeen city and across to the sea and surrounding countryside. It delivers a perspective of Aberdeen that was not previously available. Inside the building, the Library provides such activities as public lectures, a gallery, and a children's book collection that involves the University with the wider community. Technology is integrated into the building with creative use of plasma screens. A spacious and well-provided Library Café has become the most popular catering site on campus. The book stock is presented in such a way that locating print material is straightforward and easy. The Library atrium is staggering and instigates a sense of wonder in the user from all seven levels. Visitors from across the world are coming to Aberdeen to see the new Library, with the result being a higher profile for the city and its University.

Library footfall has increased dramatically from all parts of the University, which is embracing what the Library can contribute to its learning and research experiences. Those sceptical in the University about the need for developing library space are acknowledging the error of their views and are now celebrating the achievement. Aberdeen University Library provides overwhelming evidence that shows universities need to continue supplying innovative and creative physical library space for their staff and students. 


\section{References}

Caldwell, T. 2006. Future shock. Information World Review, 225, 19-22.

Childs, S. 2011. Physical Library Space and its Future. MA dissertation. Loughborough: Department of Information Science, Loughborough University. JISC. 2007. Information Behaviour of the Researcher of the Future. CIBER Briefing Paper 9. London: UCL. Available at http://www.jisc.ac.uk/media/ documents/programmes/reppres/gg_final_keynote_11012008.pdf [accessed 8 August 2012].

JISC. 2009. JISC Campaign. Libraries of the Future. Available at: http://www.jisc. ac.uk/media/documents/publications/lotfbrochure.pdf [accessed 20 April 12].

Kapp D. 1987. Designing academic libraries: Balancing constancy and change, in The forgiving building: Alibrary building consultants' symposium on the design, construction and remodelling of libraries to support a high-tech future, edited by G. Novak et al. Library Hi Tech [Online], 5(4), 82-85. Available at: http:// www.emeraldinsight.com/journals.htm? issn $=0737-8831 \&$ volume $=5 \&$ issue $=4$ [accessed 7 February 2011].

Line, M.B. 1993. Libraries and Information Services in 25 Years' Time: A British Perspective, in Libraries and the Future: Essays on the Library in the Twentyfirst Century, edited by F.W. Lancaster. New York: The Haworth Press, 73-84.

Linstone, H.A. and Turoff, M. 1975. Introduction, in The Delphi Method: Techniques and Applications, edited by H.A. Linstone and M. Turoff. Reading, MA: Addison-Wesley Publishing Company, 1-12.

Orne, J. 1977. Library building trends and their meanings. Library Journal [Online], 102(21), 2397-2401. Available at: http://connection.ebscohost. com/c/articles/5713704/library-building-trends-their-meanings [accessed 29 July 2012].

Raitt, D. 1993. The Library of the Future, in Libraries and the Future: Essays on the Library in the Twenty-first Century, edited by F.W. Lancaster. New York: The Haworth Press, 61-72.

Stahl, W.M. 1987. General observations, in Drabenstott, J. et al., Designing libraries for a high-tech future. Library Hi Tech [Online], 5(4), 104-105. Available at: http://www.emeraldinsight.com/journals.htm?issn=07378831\&volume=5\&iss $\mathrm{ue}=4 \&$ articleid $=1676048 \&$ show $=\mathrm{html}$ [accessed 7 February 2011].

Staley, D.J. and Malenfant, K. 2010. Futures Thinking for Academic Librarians: Higher Education in 2025. Association of College and Research Libraries. [Online]. http://www.ala.org/acrl/sites/ala.org.acrl/files/content/issues/value/ futures2025.pdf [accessed 20 April 2012]. 


\section{Appendix 14A Questionnaire Survey}

1. Please state your job title.

2. Below is a number of statements regarding trends in physical space use in university libraries.

3. Please mark to what extent you agree or disagree with these statements. If you have any additional comments on each of these statements, please feel free to write them next to each statement.

\section{Please indicate your response on following scale:}

\section{Strongly Agree Agree Disagree Strongly disagree}

a. 'Physical university library space is used the same way in 2011 as it was in 2001'

b. 'University libraries will increasingly share their buildings with other services'

c. 'Library buildings will be affected by reduced funding'

d. 'Physical library space is not a strategic concern'

e. 'Every campus will have a physical library in 2021'

f. 'Increases in digital information use will render the physical university library redundant'

g. 'There will be less space available for library staff in the university library of the future'

h. "Students in 2021 will think of the library as a "place of learning" rather than a "warehouse of books" 
i. 'For academic staff and researchers, physical university library space is increasingly irrelevant'

j. 'More significant differences will emerge in physical university library space depending on the different types of university'

k. 'University library space will be used in the same way in 2021 as it is in 2011'

1. Apart from economic, technological, and pedagogical factors, what are the other trends affecting university library physical space that you think will be significant? (Optional)

2. How will changes in teaching and learning impact on physical university library space in the next ten years?

3. How will changes in library support for research impact on physical university library space in the next ten years?

4. How would you justify the need for physical library space to the vicechancellor of your university in two sentences?

5. Do you have any other views on physical space in university libraries that you have not been given an opportunity to express in your previous responses? (Optional)

Thank you very much for taking the time to complete this survey.

If you would be willing to assist further via a brief interview, please give your name and email address below: (Optional) 
